\title{
Novel hybrid polyester-polyacrylate hydrogels enriched with platelet-derived growth factor for chondrogenic differentiation of adipose-derived mesenchymal stem cells in vitro
}

\author{
Fereshteh Valipour ${ }^{1,2}$, Farzaneh Valipour ${ }^{3}$, Reza Rahbarghazi ${ }^{1,4}$, Amir Mohammad Navali5,
} Mohammad Reza Rashidi ${ }^{2}$ and Soodabeh Davaran 1,2,6*

\begin{abstract}
Background: The goal of the present study was to create a new biodegradable hybrid PCL-P (HEMA-NIPAAm) thermosensitive hydrogel scaffold by grafting PNIPAAm-based copolymers with biodegradable polyesters to promote the chondrogenic differentiation of human progenitor cells (adipose-derived stem cells-hASCs) in the presence of the platelet-derived growth factor (PDGF-BB). Different mixture ratios including $50 \mathrm{mmol} \varepsilon$-caprolactone and $10 \mathrm{mmol}$ HEMA (S-1), $30 \mathrm{mmol} \varepsilon$-caprolactone and $10 \mathrm{mmol}$ HEMA (S-2), $10 \mathrm{mmol} \varepsilon$-caprolactone and $30 \mathrm{mmol}$ HEMA (S-3) were copolymerized followed by the addition of NIPAAm.

Results: A mild to moderate swelling and wettability rates were found in S-2 group copmpared to the S-1 ans S-3 samples. After 7 weeks, S-2 degradation rate reached $\sim 43.78 \%$. According to the LCST values, S-2, reaching $37^{\circ} \mathrm{C}$, was selected for different in vitro assays. SEM imaging showed nanoparticulate structure of the scaffold with particle size dimensions of about 62-85 nm. Compressive strength, Young's modulus, and compressive strain (\%) of S-2 were $44.8 \mathrm{MPa}, 0.7 \mathrm{MPa}$, and $75.5 \%$. An evaluation of total proteins showed that the scaffold had the potential to gradually release PDGF-BB. When hASCs were cultured on PCL-P (HEMA-NIPAAm) in the presence of PDGF-BB, the cells effectively attached and flattened on the scaffold surface for a period of at least 14 days, the longest time point evaluated, with increased cell viability rates as measured by performing an MTT assay $(p<0.05)$. Finally, a realtime RT-PCR analysis demonstrated that the combination of PCL-P (HEMA-NIPAAm) and PDGF-BB promoted the chondrogenesis of hASCs over a period of 14 days by up-regulating the expression of aggrecan, type-ll collagen, SOX9, and integrin $\beta 1$ compared with the non-treated control group $(p<0.05)$.
\end{abstract}

(Continued on next page)

\footnotetext{
* Correspondence: davaran@tbzmed.ac.ir

'Stem Cell Research Center, Tabriz University of Medical Sciences, Tabriz, Iran ${ }^{2}$ Department of Medicinal Chemistry, Faculty of Pharmacy, Tabriz University of Medical Sciences, Tabriz, Iran

Full list of author information is available at the end of the article
}

(c) The Author(s). 2021 Open Access This article is licensed under a Creative Commons Attribution 4.0 International License, which permits use, sharing, adaptation, distribution and reproduction in any medium or format, as long as you give appropriate credit to the original author(s) and the source, provide a link to the Creative Commons licence, and indicate if changes were made. The images or other third party material in this article are included in the article's Creative Commons licence, unless indicated otherwise in a credit line to the material. If material is not included in the article's Creative Commons licence and your intended use is not permitted by statutory regulation or exceeds the permitted use, you will need to obtain permission directly from the copyright holder. To view a copy of this licence, visit http://creativecommons.org/licenses/by/4.0/. The Creative Commons Public Domain Dedication waiver (http://creativecommons.org/publicdomain/zero/1.0/) applies to the data made available in this article, unless otherwise stated in a credit line to the data. 
(Continued from previous page)

Conclusion: These results demonstrate that the PCL-P(HEMA-NIPAAm) hydrogel scaffold carrying PDGF-BB as a matrix for hASC cell seeding is a valuable system that may be used in the future as a three-dimensional construct for implantation in cartilage injuries.

Keywords: Nanostructured scaffold, Thermosensitive hydrogel, Adipose-derived stem cells, Chondrogenesis

\section{Background}

Articular cartilage, an avascular supporting connective tissue, is composed of extracellular matrix (ECM) and functional chondrocytes [1-3]. Due to the lack of sufficient blood vessels and low cell density, the cartilage has a limited ability to self-repair and regeneration owing to its lack of blood vessels and low cell density [4]. Conventional available therapies for cartilage diseases and injuries do not completely regenerate the injured sites, leading to the formation of fibrous masses $[5,6]$.

To circumvent these pitfalls and limitations, cartilage tissue engineering is a valuable concept to enhance the repair of cartilage defects and injuries [7]. In this approach, the combination of cells, scaffolds, and growth factors may improve the functionality of cells after transplantation to the target sites $[8,9]$. Yet, in light of the limited number of tissue donors and of chondrocytes available in the cartilage for explantation, the dedifferentiation potential of these cells, and possible rejection and/or transmission of infection issues after implantation, many attempts have been developed to identify other, more reliable sources of transplantable cells $[10,11]$. Among them, mesenchymal stem cells (MSCs) were reported to exhibit a reliable chondrogenic differentiation potential, being also capable of surviving in long-term transplantation settings inside a target tissue [12]. Equally important, MSCs display immunomodulatory activities that make them a suitable allogeneic cell source for transplantation [13]. The adipose tissue is a particularly attractive source of MSCs, as it is conveniently accessible compared with other tissues such as bone marrow, synovium, dermis, peripheral blood, umbilical cord, and placenta [14, 15].

Scaffolds are critical components to promote the regeneration of cartilage injuries. These structures provide a three-dimensional (3D) environment comparable to the natural cartilage ECM. Compared with the conventional two-dimensional (2D) culture system, incubating cells in a 3D milieu provides essential cues for cell attachment and flattening, proliferation, migration, and differentiation while allowing for the synthesis of cellderived ECM [16-18]. According to previous studies, a variety of natural and synthetic polymers have been used to fabricate scaffolds to support the chondrogenic differentiation of MSCs $[19,20]$. Due to the existence of porous and water-swollen polymeric networks, hydrogels became the center of attention to generate scaffolds for many tissues and conditions [21], having the ability to initiate MSC chondrogenesis and supporting homogeneous cell seeding during encapsulation [4, 22, 23]. Poly $\mathrm{N}$-isopropylacrylamide (PNIPAAm) hydrogels have been widely investigated as thermosensitive materials with lower critical solution temperature (LCST) at around $32{ }^{\circ} \mathrm{C}$ [24]. The LCST of the hydrogel can be modulated by copolymerization of NIPAM with hydrophilic or hydrophobic monomers to increase or decrease the transition temperature, respectively [25]. Poly ( $\varepsilon$-caprolactone) (PCL) is a semicrystalline linear aliphatic polyester which combines several critical properties such as its biodegradability, biocompatibility, and good mechanical properties [26]. PCL can be degraded by hydrolysis of the ester bond in physiological conditions [27]. Unlike other polymers, PCL has less acidic degradation products and nontoxic nature, making it more suitable for implants, drug delivery, and tissue engineering applications $[28,29]$. Of note, the hydrophobicity of PLC can be diminished by incorporation with other hydrophilic polymers [30]. Poly (2-hydroxyethyl methacrylate) (PHEMA) hydrogels, for example, are appropriate scaffold materials because of their biocompatibility, hydrophilicity, softness, high water content, and permeability. To fabricate amphiphilic materials, PHEMA hydrogels are being combined with hydrophobic components to improve mechanical strength [31].

In the present study, we aimed at fabricating a novel biodegradable and thermosensitive hybrid hydrogel composed of a PCL-P(HEMA-NIPAAm) hybrid copolymer. The chondrogenic capacity of human adipose-derived MSCs (hASCs) was investigated in the presence of plateletderived growth factor (PDGF-BB) after being seeded on PCL-P(HEMA-NIPAAm). The results showed that PCL$\mathrm{P}$ (HEMA-NIPAAm) is eligible to be used as a supportive scaffold to promote the differentiation of hASCs by providing certain physio-chemical properties. The culture of hASCs in the presence of PDGFR-BB increased the chondrogenic potential of PCL-P(HEMA-NIPAAm).

\section{Materials and methods Materials}

The epsilon-caprolactone monomer $(\varepsilon-\mathrm{CL} ; 99 \% \mathrm{v} / \mathrm{v})$ and 2 hydroxyethyl methacrylate (HEMA; 97\% v/v) were purchased at Acros Organics (NJ, USA). HEMA was purified by 
vacuum distillation. $\mathrm{N}$-isopropyl acrylamide (NIPAAm) was obtained at Acros Organics and purified by recrystallization from n-hexane-toluene $(90: 10 \mathrm{v} / \mathrm{v}) .92 .5-100 \%$ Tin (II) 2ethyl hexanoate (stannous octoate, $\left.\mathrm{Sn}(\mathrm{Oct})_{2}\right)$, benzoyl peroxide (BPO), 3,6-dimethyl-1 4-dioxane-2 5-dione, and 25\% glutaraldehyde (aqueous solution) were from Sigma-Aldrich (Steinem, Germany). Dichloromethane (DCM, 99.5\% v/v), ethanol, dimethyl sulfoxide (DMSO), n-hexane, toluene, chloroform, and isopropyl alcohol were obtained at Merck Chemical (Darmstadt, Germany). Phosphate buffered saline (PBS) and $0.25 \%$ trypsin/EDTA were from Gibco (Thermo Fisher Scientific, Inc:; Waltham, MA, USA). Low-glucose content Dulbecco's modified Eagle medium (DMEM/LG) was obtained from Biowest (Nuaille, France). 3-(4,5-dimethylthiazol-2-yl-2,5-diphenyltetrazolium bromide) (MTT) and the penicillin-streptomycin (pen-strep) solution were purchased at Invitrogen Life Sciences (Nottingham, UK). Fetal bovine serum (FBS) was obtained from PAN Biotechnology (Aidenbach, Germany). Recombinant Human PDGF-BB peptide CF was purchased at R\&D Systems (Minneapolis, MN, USA). The anti-CD133 (13A4), anti-CD44 (IM7), antiCD34 (RAM34), and anti-CD45 (F10-89-4) antibodies were from eBioscience (San Diego, USA). PE- and FITCconjugated secondary antibodies were from the same company (San Diego, USA). The SMART ${ }^{\mathrm{mm}}$ BCA (Bicinchoninic Acid) Protein Assay Kit was purchased at Intron Biotechnology (Sungnam, Korea). The TRIzol ${ }^{\text {Tw }}$ reagent was purchased from Yekta Tajhiz Company (Tehran, Iran).

\section{Synthesis of the HEMA-PCL macromonomer}

The HEMA-PCL macromonomer was synthesized by ring-opening polymerization of $\varepsilon$-caprolactone in the presence of HEMA as an initiator and stannous octoate as a catalyst without solvent in bulk conditions [32]
(Fig. 1). Different mixture ratios including $5.707 \mathrm{~g}$ (50 mmol) $\varepsilon$-caprolactone and $1.3 \mathrm{~g}(10 \mathrm{mmol})$ HEMA (S-1), $3.425 \mathrm{~g}$ (30 mmol) $\varepsilon$-caprolactone and $1.3 \mathrm{~g}(10 \mathrm{mmol})$ HEMA (S-2), $1.142 \mathrm{~g}(10 \mathrm{mmol}) \varepsilon$-caprolactone and $3.9 \mathrm{~g}$ (30 mmol) HEMA (S-3) were stirred individually at $110{ }^{\circ} \mathrm{C}$ in a nitrogen atmosphere for $30 \mathrm{~min}$. Subsequently, a catalytic amount of $\mathrm{Sn}(\mathrm{Oct})_{2}$ (with an initial weight ratio of $0.05 \mathrm{wt} \%$ of the total monomer amount) was dissolved in about $0.5 \mathrm{ml}$ of anhydrous toluene and added to the mixture. The reaction was carried out at $110^{\circ} \mathrm{C}$ for $4 \mathrm{~h}$ under nitrogen atmosphere in a stirred flask, and the temperature was precisely controlled by an external oil bath. All the macromonomers produced were refrigerated at $4{ }^{\circ} \mathrm{C}$ until use. After cooling to RT, the resulting product was dissolved in $\mathrm{CHCl}_{3}$. The solution was added dropwise into the excess ethanol to precipitate. The obtained macromonomer was dried in a vacuum at $\mathrm{RT}$. The structure of the macromonomer was characterized by Fourier-transform infrared spectroscopy (FT-IR).

\section{Synthesis of the PCL-P(HEMA-NIPAAm) hybrid copolymer} PCL-P(HEMA-NIPAAm) hybrid copolymers were synthesized by free-radical copolymerization of NIPAAm $(10 \mathrm{~g})$ and HEMA-PCL macromonomers $(3.33 \mathrm{~g})$ in 1,4dioxane $(50 \mathrm{ml})$ under nitrogen atmosphere (Fig. 1). The mixture was degassed under nitrogen atmosphere for 30 min before polymerization. BPO at a concentration of $0.05 \mathrm{wt} \%$ of the total weight of macromonomer and NIPAAm was used as a copolymerization initiator. The polymerization was carried out at $70^{\circ} \mathrm{C}$ for $24 \mathrm{~h}$ under a nitrogen atmosphere [33, 34]. After reaching $\mathrm{RT}$, the product was purified by dissolution/precipitation with dichloromethane/ethanol solution and then dried in a

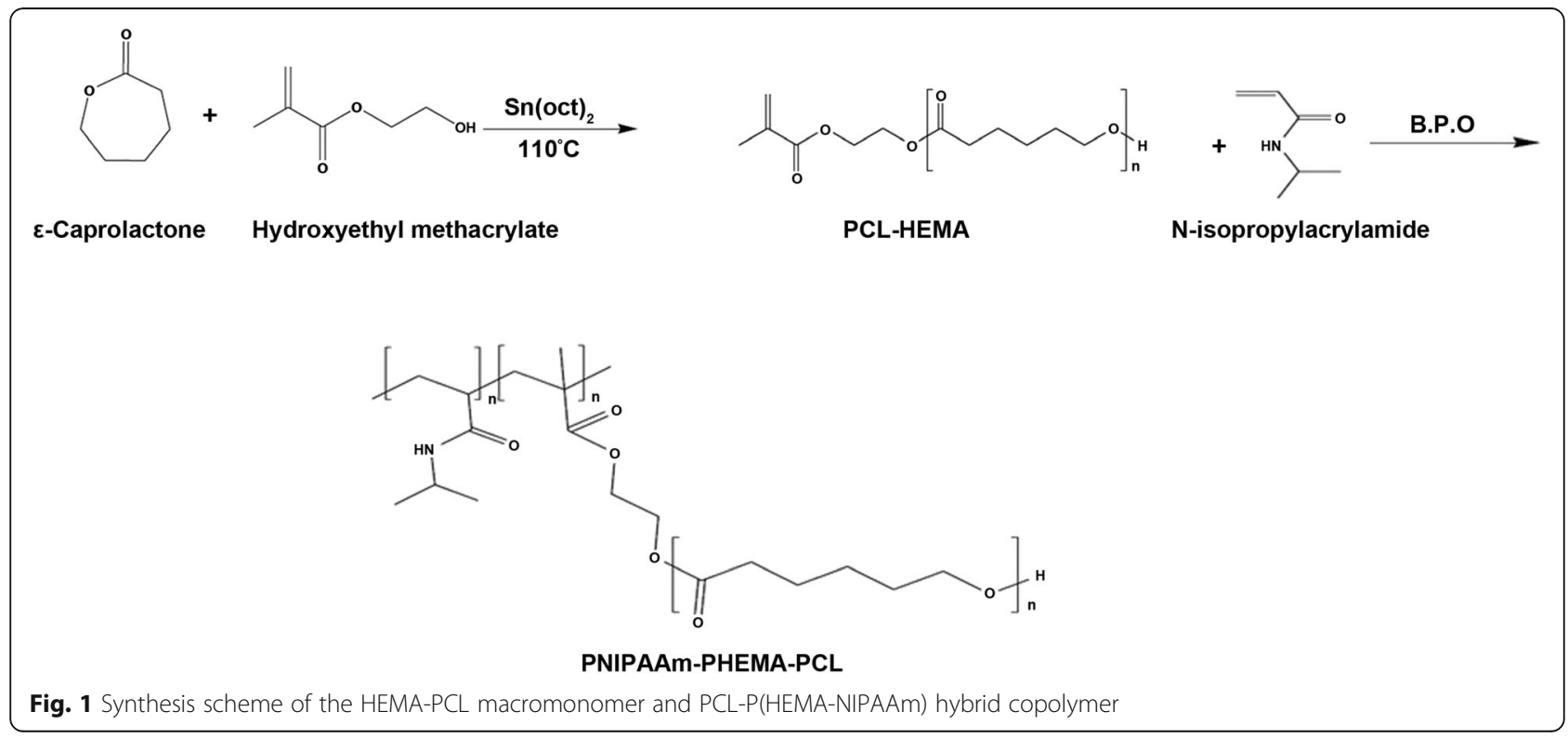


vacuum at $\mathrm{RT}$. The purified product was lyophilized and stored at $4{ }^{\circ} \mathrm{C}$ until use. The structure of the cross-linked hydrogel was characterized by FT-IR and ${ }^{1} \mathrm{H}-\mathrm{NMR}$.

\section{System characterization methods}

FT-IR spectra of the synthesized HEMA-PCL macromonomer and PCL-P(HEMA-NIPAAm) hybrid copolymer were obtained in the range of 4000 to $400 \mathrm{~cm}^{-1}$ using an FT-IR spectrometer (Tensor 27 spectrophotometer, Bruker; Avance, Germany). The samples were ground and mixed thoroughly with potassium bromide. The final concentration of each sample in $\mathrm{KBr}$ was $1 \%$. The chemical composition of the PCL-P(HEMA-NIPAAm) hybrid copolymer was analyzed by hydrogen nuclear magnetic resonance $\left({ }^{1} \mathrm{HNMR}\right)$ spectroscopy at $400 \mathrm{MHz}$ using a Bruker spectrometer (Ettlingen, Germany) and deuterated chloroform $\left(\mathrm{CDCl}_{3}\right)$ as a solvent. To investigate the wettability and hydrophobicity of scaffolds, water contact angles test was performed. Static water contact angles of scaffolds were carried out through the sessile drop method by a goniometer (Model no. CA-500A; Sharifsazan; Tabriz, Iran) at room temperature. For this purpose, the scaffolds were cut into square specimens with the size of $1 \mathrm{~cm} \times 1 \mathrm{~cm}$. Subsequently, $2 \mu \mathrm{l}$ distilled water was dropped onto the each scaffold surface. The water contact angle was obtained after $10 \mathrm{~s}$ and the drop dimension parameters were automatically calculated from the digitalized image. The measurements recorded were an average of at least five contact angles obtained on three samples. The experiments were performed at least in triplicate. The rate of water absorption of the synthesized porous scaffolds was measured by the gravimetric method in $\mathrm{PBS}$ with $\mathrm{pH}=7.4$ at physiological temperature $\left(37^{\circ} \mathrm{C}\right)$. The dried scaffolds were cut into similar size particles and weighted before incubation $\left(W_{d}\right)$. Scaffolds were immersed in PBS buffer solution at predetermined times. The scaffolds were taken out and their wet weight was determined $\left(\mathrm{W}_{\mathrm{w}}\right)$ by the exclusion of excess surface water using filter paper [35]. The ratio of swelling was calculated using eq. 1:

$$
\text { swelling ration }=\left(\mathrm{W}_{\mathrm{w}}-\mathrm{W}_{\mathrm{d}}\right) / \mathrm{W}_{\mathrm{d}}
$$

All experiments were performed triplicate and the average values have been reported in the scheme. To evaluate the in vitro degradation of synthesized hydrogels, all the samples were lyophilized and weighed before $\left(\mathrm{W}_{0}\right)$ and after $\left(\mathrm{W}_{\mathrm{t}}\right)$ soaking in $\mathrm{PBS}$ with $\mathrm{pH}=7.4$ at $37^{\circ} \mathrm{C}$ in respective times [36]. The samples were then removed from the solution, vacuum-dried at RT to reach a constant weight, and weighed again. The hydrogel degradation rate was measured by monitoring the weight loss over time using eq. 2 :

$$
\text { \%weight loss }=\left[\left(\mathrm{W}_{0}-\mathrm{W}_{\mathrm{t}}\right) / \mathrm{W}_{0}\right] \times 100 \%
$$

where $\mathrm{W}_{\mathrm{t}}$ is the initial dry weight of the sample and $\mathrm{W}_{0}$ is the dry weight of the sample after a specific degradation period. The culture medium was replenished every 3-4 days. Three sets of experiments were performed. To determine the LCST of PCL-P(HEMA-NIPAAm) hybrid hydrogels, the cloud point $(\mathrm{CP})$ measurement (turbidimetry) method was used. Optical transmittance of aqueous polymer solution at various temperatures was measured at the wavelength of $500 \mathrm{~nm}$ using a UV-Vis spectrometer (UV-160 Shimadzu) with increasing solution temperatures $\left(18-50^{\circ} \mathrm{C}\right)$. The heating rate was $1{ }^{\circ} \mathrm{C} / \mathrm{min}$. At each step, the samples were stabilized for $10 \mathrm{~min}$ before the next measurements [33]. Values for the LCST of polymeric solutions were determined as the temperature at the inflection point in the normalized absorbance versus the temperature curve.

\section{Mechanical evaluations}

The mechanical properties of the scaffold were calculated using the universal material testing machine STM250 (Santam; Tehran, Iran). Hydrogel samples were equilibrated for 3 days at $37^{\circ} \mathrm{C}$ in $\mathrm{PBS}$ before testing. Hydrogel samples were cut into cubes $(5 \times 5 \times 5.74 \mathrm{~mm})$. The sample was placed on the sample plate of the compression tester. To study mechanical properties, the scaffolds were mechanically analyzed in compression using a $5 \mathrm{~N}$ load cell with a loading rate of $2 \mathrm{~mm} / \mathrm{min}$ [37]. Using values obtained from the force and compression analyses, the stress-strain curves were plotted followed by calculation of Young's modulus index.

\section{Scanning electron microscopy (SEM)}

Morphological studies of the fabricated scaffold before and after cell culture were investigated using field emission scanning electron microscopy FESEM (JEOL, JSM 6700F model) (JEOL Ltd.; Tokyo, JAPAN). hASCs were seeded on the freeze-dried scaffold at a density of $5 \times 10^{4}$ cells $/ \mathrm{cm}^{2}$ and cultured 7 days with medium replenished every 2-3 days. After reaching appropriate confluency, scaffolds harboring hASCs were washed twice with PBS, fixed in $2.5 \%$ glutaraldehyde solution at RT for $2 \mathrm{~h}$, rinsed three times with PBS, and dehydrated at the increasing percentage of ethanol $(25-100 \%)$ for $20 \mathrm{~min}$ [38]. The samples were then dried overnight at RT and finally prepared for SEM utilizing a gold coating method and displayed at $15 \mathrm{kV}$.

\section{Serum protein adsorption capacity}

To assess the possible capacity of the fabricated scaffold to adsorb different protein types, we measured the total content after incubation of scaffold with serum. For this purpose, scaffolds were cut in equal size and placed in 96-well plate, suspended in a $200 \mu \mathrm{l}$ culture medium (DMEM/LG containing 10\% FBS) and maintained inside 
an incubator at $37^{\circ} \mathrm{C}$ for 2 weeks. Thereafter, the supernatant was collected and stored in microtubes. Then, the scaffolds were chopped into small pieces and $1 \mathrm{ml}$ of serum-free media was added to it. The media was removed from the scaffolds and centrifuged at $14,000 \mathrm{rpm}$ for $10 \mathrm{~min}$ to yield homogeneous liquid. The media was then collected again in another microtube to measure the levels of adsorbed protein. In the current experiment, we measured the protein concentration using the SMART $^{\mathrm{ma}}$ BCA (Bicinchoninic Acid) Protein Assay Kit according to the manufacturer's instructions. In short, $25 \mu \mathrm{l}$ of each standard (bovine serum albumin - BSA), control, and protein samples were pipetted into a 96well plate, and $150 \mu \mathrm{l}$ of working solution (WS) to each well and mixed plate thoroughly on a plate shaker for $30 \mathrm{~s}$. Then, the plates were covered and incubated at $37^{\circ} \mathrm{C}$ for $2 \mathrm{~h}$. The plate cooled to RT. Serum-free medium was used as blank. The absorbance of each well was at $570 \mathrm{~nm}$ using a microplate reader (BioTek; VT, USA). The experiments were performed in triplicate.

\section{Isolation and expansion of hASCs}

To isolate hASCs, six normal women, ranging from 45 to 48 years old, were enrolled in the current experiment who referred to liposuction surgery at the Imam Reza Hospital, an affiliated hospital to Tabriz University of Medical Sciences (Tabriz, Iran). All procedures of the study were approved by the local ethics committee of Tabriz University of Medical Sciences (IR.TBZMED.REC.1395.74). To obtain samples, all volunteers were asked to complete and signed the informed consent forms. The samples were kept in PBS solution enriched with $1 \%$ Pen-Strep solution and transferred quickly to the Stem Cell Research Center, Tabriz University of Medical Sciences. Then, samples were carefully chopped into small size and incubated with an enzymatic solution containing $1 \%$ type 1 collagenase plus $0.25 \%$ Trypsin/ EDTA at $37^{\circ} \mathrm{C}$ for $30-40 \mathrm{~min}$. The samples were continuously shaken to facilitate the release of cells from the tissue mass. Finally, the suspensions containing enzymes were blocked using FBS. Samples were centrifuged at $1000-2000 \mathrm{rpm}$ and the cell pellet was resuspended in DMEM/LG supplemented with 10\% FBS and $1 \%$ pen-strep. The cells were maintained in an incubator at $37^{\circ} \mathrm{C}$ and a humidified atmosphere with $5 \%$ $\mathrm{CO}_{2}$. The supernatant medium was replaced every 2-3 days until $70-80 \%$ confluence. $0.25 \%$ trypsin/EDTA was used to detach and passaged the hASCs. Cells (passages 3-6) were employed in the experiments using the following groups: [hASCs], [hASCs + PDGF-BB], [hASCs + scaffold], and [hASCs + scaffold + PDGF-BB] using $10 \mathrm{ng} / \mathrm{ml}$ of PDGF-BB.

\section{Flow cytometry}

hASCs were characterized for the expression of CD133, CD44, CD34, and CD45 by flow cytometric analysis. Cells at passage 3 were detached using $0.25 \%$ trypsin/ EDTA, incubated with $1 \%$ BSA, and permeabilized with $0.1 \%$ triton-X100. After three washes with PBS, the cells were incubated with PE- and FITC-conjugated secondary antibodies at $4{ }^{\circ} \mathrm{C}$ for $30 \mathrm{~min}$ according to the manufacturer's recommendations. $1 \times 10^{5}$ cells were analyzed using BD FACSCalibur and FlowJo software (version 7.6.1) (TreeStar, Inc.; Ashland, OR, USA).

\section{Cytotoxic assay}

The possible cytotoxicity of the synthesized scaffold on hASCs was assessed using the MTT assay. The scaffolds were lyophilized and sterilized after exposure to UV light in a laminar flow hood. Scaffolds $(10 \mathrm{~mm} \times 10 \mathrm{~mm} \times 6$ $10 \mathrm{~mm}$ ) were placed in 96-well plates followed by the addition of $200 \mu \mathrm{l} \mathrm{DMEM/LG} \mathrm{containing} \mathrm{1 \%} \mathrm{pen-strep}$ and $10 \%$ FBS. Plates were temporarily incubated at $37^{\circ} \mathrm{C}$ for $30 \mathrm{~min}$. The medium was next removed and $150 \mu \mathrm{l}$ DMEM/LG containing 10\% FBS and 1\% pen-strep with a density of $10^{4}$ hASCs/well were added to each well and kept for 14 days under conventional condition. After completion of incubation time, the medium was discarded and $50 \mu \mathrm{l}$ MTT solution $(5 \mathrm{mg} / \mathrm{ml})$ was added to each well. The plates were maintained at $37^{\circ} \mathrm{C}$ for $4 \mathrm{~h}$. Thereafter, the supernatants were semi-replaced by 100 $\mu \mathrm{l}$ of DMSO, and the plates were gently shaken for 15 min to dissolve formazan crystals [39]. The homogenous blue colored supernatants were next transferred to the fresh 96-well plates. Absorbance values of each well were measured by absorbance reading at $570 \mathrm{~nm}$ in an ELISA reader (BioTek). The final ODs were measured and expressed as \% of control hASCs and experiments were carried out in triplicate. hASCs seeded on standard plastic culture surfaces were used as controls.c

\section{Real-time RT-PCR analysis}

To evaluate the chondrogenic potential of scaffold on hASCs, cells were plated in each well of 6-well plates for 14 days and the expression of aggrecan, type-II collagen, SOX9, and integrin $\beta 1$ was measured by real-time RTPCR analysis, with glyceraldehyde-3-phosphate dehydrogenase (GAPDH) serving as a housekeeping gene and internal control (Table 1). After completion of cell culture, the media was aspirated and the cells were lysed directly by adding $1 \mathrm{ml}$ of TRIzol ${ }^{\mathrm{Tm}}$ reagent. After several pipetting, the homogenized samples were incubated at $25^{\circ} \mathrm{C}$ for $5 \mathrm{~min}$ to permit the complete dissociation of nucleoprotein complexes. Then, $0.2 \mathrm{ml}$ of chloroform solution was added and sample tubes capped securely and tubes were shaken vigorously followed by centrifugation at 12 , $000 \mathrm{xg}$ at $4{ }^{\circ} \mathrm{C}$ for $5-10 \mathrm{~min}$. The mixture was separated 
Table 1 Primers employed in the real-time RT-PCR analysis

\begin{tabular}{lll}
\hline Genes & Sequences & $\mathbf{T}_{\mathbf{m}}\left({ }^{\circ} \mathbf{C}\right)$ \\
\hline Aggrecan & $\begin{array}{l}\text { Forward: 5'-CCATCTCTACACGCTACACCC-3' } \\
\text { Reverse: 5'-TTGTCTCCATAGCAGCCTCC-3' }\end{array}$ & $60{ }^{\circ} \mathrm{C}$ \\
Type-II collagen & $\begin{array}{l}\text { Forward: 5'-CGTCTACCCCAATCCAGCAAA-3' } \\
\text { Reverse: 5'-AGCAGGCGTAGGAAGGTCAT-3' }\end{array}$ & $60{ }^{\circ} \mathrm{C}$ \\
SOX9 & $\begin{array}{l}\text { Forward: 5'-CACACTCCTCCTCCGGCATGA-3' } \\
\text { Integrin } \beta_{1}\end{array}$ & $63{ }^{\circ} \mathrm{C}$ \\
& Reverse: 5'-GCGGAAGTCGATAGGGGGCT-3' & \\
GAPDH & Reverse: 5'-CATTCCTGTGTGCATGTGTCTT-3' & \\
& Forward: 5'-AGCCAAAAGGGTCATCATCTCT-3' & $60{ }^{\circ} \mathrm{C}$ \\
& Reverse: 5'-AGTCCTTCCACGATACCAAAGT-3' & \\
\hline
\end{tabular}

into a lower yellow, phenol-chloroform phase, interphase, and a colorless upper aqueous phase. The aqueous phase was transferred to a fresh tube. RNA was precipitated from the aqueous phase by mixing with 0.5 $\mathrm{ml}$ of isopropyl alcohol. Finally, the concentration of isolated RNAs was calculated based on the OD ${ }^{260 / 280 ~ n m}$ ratio measurement by NanoDrop (NanoDrop one c, Thermo Fisher Scientific; MA, USA). By using cDNA synthetase (Yekta Tajhiz; Tehran, Iran), RNAs were reverse-transcribed into cDNA. Real-time RT-PCR was performed using the YTA SYBR Green qPCR Master Mix 2X kit on a Rotor-Gene Q (Qiagen; Hilden, Germany) real-time instrument. Fold change expression of each sample, calculated by the $2^{-\Delta \Delta C T}$ method. Each sample type was run in triplicate. hASCs seeded on standard plastic culture surfaces (without scaffold and PDGF-BB) were used as controls.

\section{Statistical analysis}

Data are expressed as mean \pm standard deviation (SD). The statistical difference between groups was calculated using the One-ANOVA assay and Tukey post hoc analysis (GraphPad Software, San Diego, CA, USA), with $p<0.050$ considered statistically significant $(* p<0.050$; *** $p<0.010 ; * * * * 0.001 ; * * * * * 0<0.0001)$.

\section{Results and discussion}

Fourier-transform infrared spectroscopy (FT-IR) analysis

FT-IR was first performed to investigate the chemical structure of the synthesized hybrid PNIPAAm-polyester scaffold. The FT-IR spectrum of the HEMA-PCL macromonomer and PCL-P(HEMA-NIPAAm) hybrid copolymer are presented in Fig. $2 \mathrm{a}$ and $\mathrm{b}$, respectively. The spectrum of the HEMA-PCL macromonomer exhibited a characteristic stretching vibration peak for the ester carbonyl $(\mathrm{C}=\mathrm{O})$ at $1725 \mathrm{~cm}^{-1}$ and a broad peak at 3530 $\mathrm{cm}^{-1}$ for hydroxyl group $(-\mathrm{OH})$. The bands at 2945 and $2820 \mathrm{~cm}^{-1}$ are attributed to the stretching vibrations of $\left(-\mathrm{CH}_{2}\right)$ and $\left(-\mathrm{CH}_{3}\right)$. Moreover, there was an adsorption a<smiles>CC(C)CCCCCCCCCCCC(C)C(C)C</smiles>

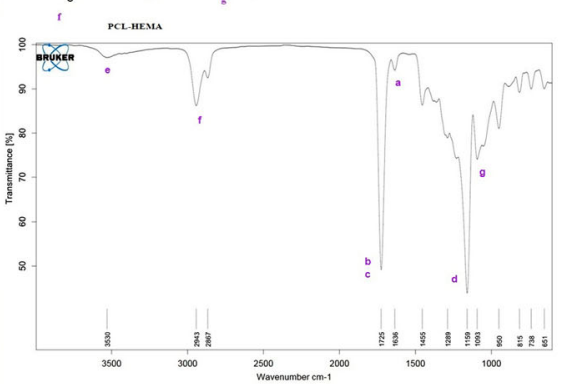

b

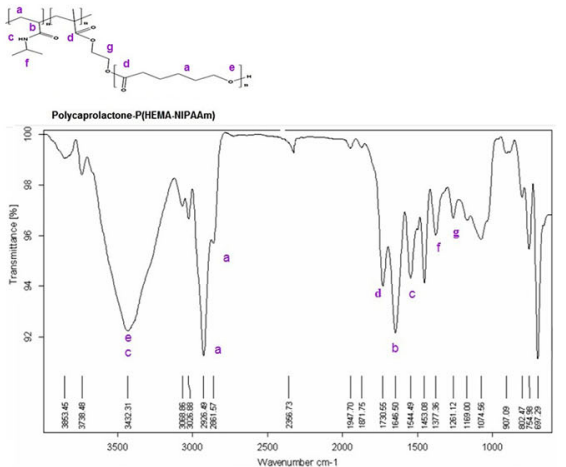

C

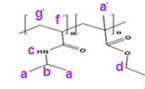

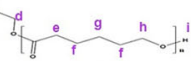
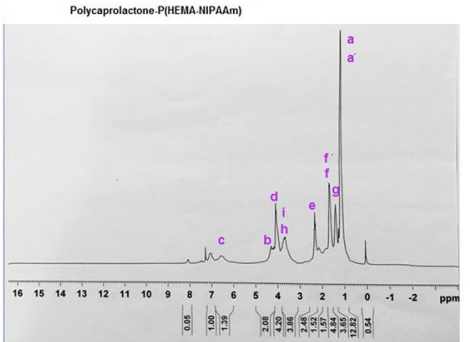

Fig. 2 FT-IR spectra of the PCL-HEMA macromonomer (a). FT-IR spectra of the PCL-P(HEMA-NIPAAm) hybrid copolymer (b). ${ }^{1} H N M R$ spectrum of the PCL-P(HEMA-NIPAAm) hybrid copolymer (c) 
band at $1636 \mathrm{~cm}^{-1}$ which is from the $(\mathrm{C}=\mathrm{C})$ stretching vibration of HEMA. The peak at $1159 \mathrm{~cm}^{-1}$ is the stretching vibration absorption peak of $(\mathrm{C}-\mathrm{O}-\mathrm{C})$ from HEMA and PCL. The peak at $1454 \mathrm{~cm}^{-1}$ is assigned to the bending vibration of $\left(-\mathrm{CH}_{2}-\right)$ groups. The PCLP(HEMA-NIPAAm) copolymer (Fig. 2b) exhibited the characteristic absorption signals of amide functional groups of poly(NIPAAm) at $1646 \mathrm{~cm}^{-1}$ (NH-COstretching), $1544 \mathrm{~cm}^{-1}$ (N-H bending), and $1377 \mathrm{~cm}^{-1}$ correspondings to the $\mathrm{C}-\mathrm{H}$ vibrations of $-\mathrm{CH}\left(\mathrm{CH}_{3}\right)_{2}$ (41). The main absorption bands in this copolymer were the stretching vibrations of carbonyl groups of PHEMA, PCL at $1730 \mathrm{~cm}^{-1}$, and PNIPAAm at $1652 \mathrm{~cm}^{-1}$. The characteristic absorption band of the vinyl group at $1636 \mathrm{~cm}^{-1}$ was not observed, indicating that the HEMA monomer was successfully converted to the PHEMA polymer through the free radical polymerization reaction [40]. The absorption bands due to $(-\mathrm{NH}$ secondary amid) and hydroxyl groups were overlapping and led to a very strong and broadband centered at $3456 \mathrm{~cm}^{-1}$. The absorption at 2661 and $2926 \mathrm{~cm}^{-1}$ corresponds to aliphatic $-\mathrm{CH}$ stretching vibrations of $\left(-\mathrm{CH}_{3}\right)$ and $\left(-\mathrm{CH}_{2}-\right)$ groups.

Hydrogen nuclear magnetic resonance ('HNMR) spectrum The ${ }^{1} \mathrm{HNMR}$ spectrum (in $\mathrm{CDCl}_{3}$ ) of the PCL-P(HEMANIPAAm) copolymer was used to determine the structure and composition of the copolymer (Fig. 2c). The peak of methylene's $\left(\mathrm{CH}_{2}\right)$ in PCL was seen around $1.381 \mathrm{ppm}(2 \mathrm{H}, \mathrm{g}), 1.646 \mathrm{ppm}(2 \mathrm{H}, \mathrm{f}), 2.333 \mathrm{ppm}(2 \mathrm{H}, \mathrm{e})$, and $3.685 \mathrm{ppm}(2 \mathrm{H}, \mathrm{h})$. The signals at $6.56 \mathrm{ppm}(\mathrm{H}, \mathrm{c})$, $4.209 \mathrm{ppm}(\mathrm{H}, \mathrm{b})$, and $1.31 \mathrm{ppm}(3 \mathrm{H}, \mathrm{a})$ correspond to protons of $\left(\mathrm{NH}-\mathrm{CH}\left(\mathrm{CH}_{3}\right)_{2}\right),\left(-\mathrm{CH}\left(\mathrm{CH}_{3}\right)_{2}\right)$ and methyl groups in the PNIPAAm segment. Overlapping resonance was related to methyl of the ester group $\left(-\mathrm{OCCH}_{2}-\right.$ ) at $4.158 \mathrm{ppm}(2 \mathrm{H}, \mathrm{d})$ in the PHEMA-PCL segment. The removal of the peaks at $5.58 \mathrm{ppm}$ and $6.11 \mathrm{ppm}$ indicates that end double bonds were converted into carbon-carbon signal bonds to form the main chain during polymerization [41]. All the evidence proved a graft copolymer was successfully synthesized [33, 42].

\section{Water contact angle measurement}

Wettability refers to the ability of scaffolds to adsorb water which is touted as primary concern both in vitro and in vivo culture systems [43]. Hydrophilic surfaces with small contact angles (less than $90^{\circ}$ ) corresponded to high wettability, while hydrophobic surfaces with large contact angles (more than $90^{\circ}$ ) corresponded to low wettability [43]. In this study, we evaluated the relative hydrophilicity of scaffolds by measuring their water contact angles using a sessile drop method (Fig. 3a). Data revealed that water contact angles of S-1, S-2 and S-3 scaffolds were $70.07 \pm 2.7,53.23 \pm 1.0$ and $42.98 \pm 3.8$ degrees. It has shown that the contact angle of the scaffolds has propotional correlation with the levels of PCL and reduction PHEMA in the final components. Therefore, we can changes waterabiltiy index by the alteration of PCL and P(HEMA). The enhancement in the wettability can improve the cell attachment, proliferation and mutual interaction of cells with the scaffolds [43]. Considering the efficiency of mild to moderate wettability index in the growth dynamics, we selected S-2 scaffold for subsequent assays.

\section{Swelling studies of the PCL-P(HEMA-NIPAAm) hydrogels}

The swelling capability of the scaffold correlates with the cell infiltration into the scaffolds in a 3D culture system [44]. It also increases the surface area, allowing cells to adhere to the surface of the scaffold and the samples to be available for nutrients from culture media more effectively [45]. Excessive swelling may lead to an increased pore size while affecting the attachment and proliferation of cells. In contrast, a lower swelling degree could help to enhance scaffold mechanical stability [46]. Thus, a scaffold with a controlled swelling ratio is desired for the regeneration of different tissues. The equilibrium swelling ratios and swelling profile as a function of time for the PCL-P(HEMA-NIPAAm) hydrogels containing a fixed concentration of NIPAAM and different concentration of CL and HEMA are illustrated in Fig. 3b. All scaffolds had similar swelling behaviors as a function of time and showing controlled swelling behavior in the PBS medium. The swelling ratio increased with an increase in the hydrophilic HEMA content. According to the data, the addition of the hydrophobic PCL segment decreased the swelling rate. This result is supported by a study, which reported by Chao et al. [47]. In this study, the swelling ratio of S-3 was higher than that of S-2 and S- 1 at $\mathrm{pH}=7.4$ and $37^{\circ} \mathrm{C}$.

\section{In vitro degradation of the PCL-P(HEMA-NIPAAm) hydrogels}

The degradation ability of a hydrogel scaffold is a vital parameter for successful scaffold fabrication [45]. To achieve long-term mechanical stability and reliability, scaffolds should degrade slowly over time in a controlled manner. The hydrolysis of the hydrogels was studied in simulated physiological conditions in a buffer solution of $\mathrm{pH} 7.4$ at $37^{\circ} \mathrm{C}$. As shown in Fig. 3c, the degradation rate was mainly determined by the biodegradability of the PCL segment. The hydrolytic degradation rate of the scaffolds was increased with the increasing content of PCL in the hydrogels. PCL segments were hydrolytic degradable, and weight loss of the hydrogels was mainly caused by cleavage of ester bonds within the network in PCL segments. This finding is consistent with the results reported by Chao et al. [47]. In conclusion, weight loss 


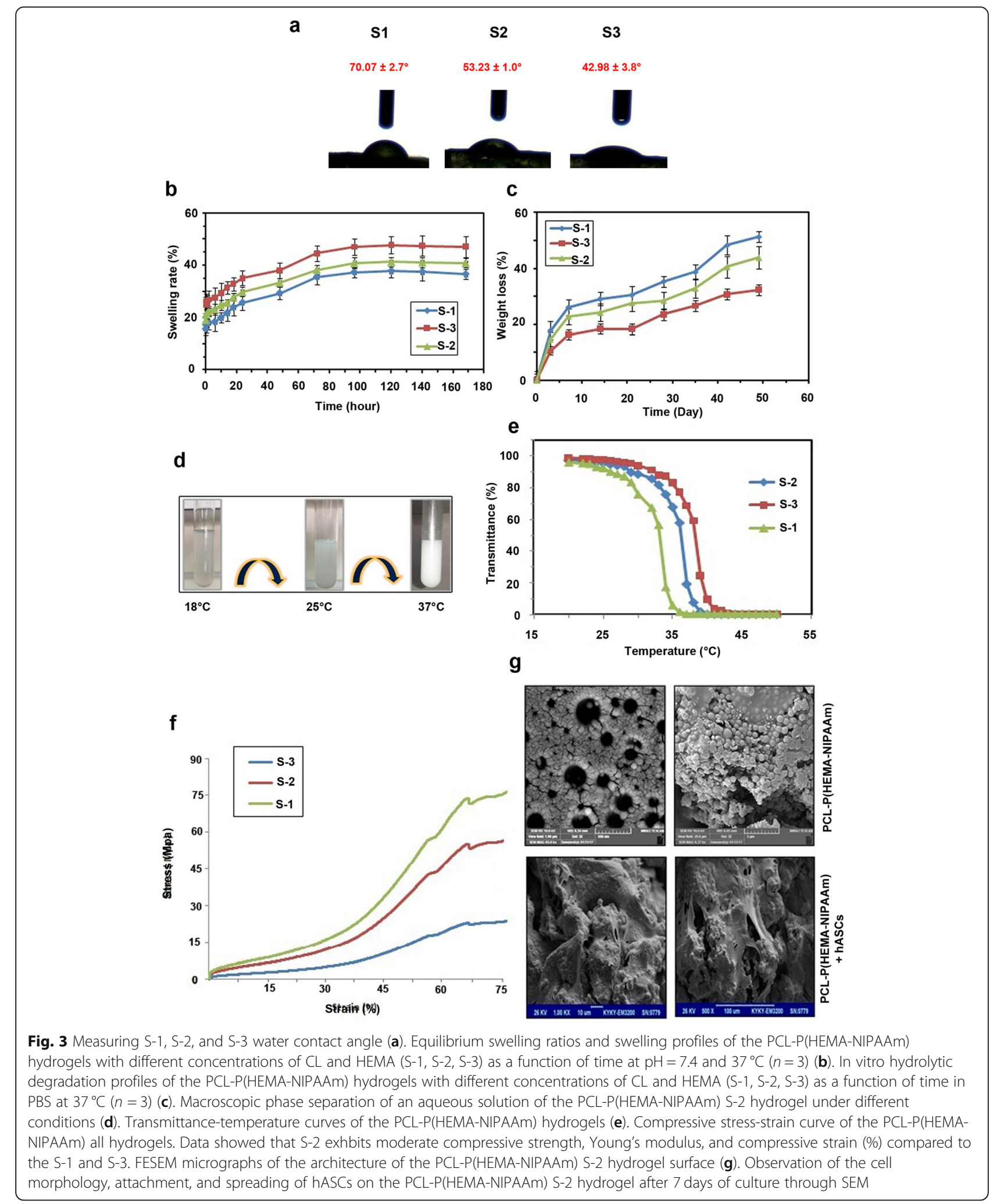

of the hydrogels increased with increase in PCL content or decrease in HEMA content. In the current experiment, the hydrogels exhibited a substantial weight loss, approximately $32.33 \%$ (S-1), $43.78 \%$ (S-2), and $51.24 \%$ (S-3) of its initial mass after 7 weeks. Concretely, the use of slowly degrading scaffolds gives the constructs 
evaluated in this study long-term stability, maintaining a biomechanically functional framework that supplies seeded cells substantial time to synthesize a new ECM.

\section{LCST and phase transition behavior of the PCL-P(HEMA- NIPAAm) hydrogels}

LCST of the hydrogels was investigated by the turbidity method by monitoring the change in the optical absorbance as a function of temperature (Fig. 3d-e). The results confirmed a similar sharp phase transition for hydrogels with a small temperature change. The sharp reduction in UV transmittance indicates that the hydrogels become increasingly turbid with shrinking on increasing at higher temperatures, and the LCST is the point at which the network structure of polymer collapse and water expelled of the hydrogel. As indicated in Fig. 3d-e and Table 2, LCST values of the hydrogels were obtained with a constant concentration of NIPAAm and different concentrations of $\mathrm{CL}$ and HEMA at $34^{\circ} \mathrm{C}, 37^{\circ} \mathrm{C}$, and $39^{\circ} \mathrm{C}$, respectively. The ability of hydrogels to absorb water arises from hydrophilic functional groups and hydrogen bonding ability between polymer and water increases, whereas the LCST of hydrogels decreased when increasing the hydrophobic PCL segment because the hydrophobic comonomer facilitates chain aggregation [48]. Figure 3d-e shows the visual macroscopic observation of phase separation of aqueous hydrogel solution below and above LCST. As illustrated in Fig. 3d-e, below the LCST the solution of the hydrogel is clear but upon heating, at $37^{\circ} \mathrm{C}$, the solution became turbid because of the aggregation of the hydrogel. It is important to note that the LSCT of the S-2 hydrogel is similar to the body temperature, a valuable feature for biological applications. According to these results, S-2 was selected for further biological assays.

\section{Mechanical properties of the PCL-P(HEMA-NIPAAm) hydrogels}

Compressive property is one of the most important mechanical characteristics of scaffolds that are especially vital for hydrogels used in tissue engineering [49]. Scaffolds should have sufficient mechanical strength to withstand mechanical stress to provide the appropriate

Table 2 Composition and LCST of PCL-P(HEMA-NIPAAm) hybrid hydrogels

\begin{tabular}{lllll}
\hline Groups & $\mathbf{C L}(\mathbf{g})$ & HEMA $(\mathbf{g})$ & PCL-HEMA ratio & LCST $\left({ }^{\circ} \mathbf{C}\right)$ \\
\hline S-1 & 5.707 & 1.3 & $5: 1$ & 34 \\
S-2 & 3.425 & 1.3 & $3: 1$ & 37 \\
S-3 & 1.142 & 3.9 & $1: 3$ & 39
\end{tabular}

Final wt\% of NIPAAm was equal in all groups (70\% NIPAAm:30\% PCL-HEMA). Abbreviations: CL Caprolactone, HEMA 2-hydroxyethyl methacrylate, PCL Poly ( $\varepsilon$ caprolactone), LCST Lower critical solution temperature, NIPAAm

$\mathrm{N}$-isopropyl acrylamide biomechanical environment needed for cell migration, proliferation, and differentiation [37]. To this end, the scaffolds used in tissue engineering should have adequate structural stability to retain their initial shape at the implant site until their function gets completed [50]. To study the mechanical behavior of the prepared scaffolds, the mechanical strength of the scaffolds was investigated via the uniaxial compression technique. The typical stress-strain plot of the PCL-P(HEMA-NIPAAm) hydrogels is illustrated in Fig. 3f. As seen in the diagram, the stress-strain curve of three scaffolds exhibits three distinct regions: linear elastic behavior at low stress, non-linear shifting strain at intermediate stress, and linear elastic behavior at high stress. The modulus of elasticity (E) was calculated as the slope of the linear portion of the stress-strain curve. The compressive strength, Young's modulus, and compressive strain (\%) of the S-3 were highest while we achieved lowest values for S-1. The intermediate compressive strength, Young's modulus, and compressive strain (\%) were reported for the S-2 (44.8 $\mathrm{MPa}, \quad 0.7 \mathrm{MPa}$, and $75.5 \%$, respectively). The Young's modulus of cartilage is in the range of 0.45 $0.90 \mathrm{MPa}$ [51]. Based on compressive modulus results, the PCL-P(HEMA-NIPAAm) hydrogel may be the most suitable candidate for cartilage engineering.

\section{SEM analysis of the PCL-P(HEMA-NIPAAm) S-2 hydrogel}

The morphology of the fabricated freeze-dried S-2 scaffold was demonstrated by FESEM micrographs before and after cell culture (Fig. 3g). SEM micrographs were used to study the attachment, morphology, and spreading of cells on the scaffolds. According to Fig. 3g, the PCL-P(HEMA-NIPAAm) hydrogel had a nanoparticulate structure with particle size dimensions about $62-85$ $\mathrm{nm}$ with uniform and highly interconnected porous structures. The minimum and maximum sizes of the pores ranged between 8 to $14 \mu \mathrm{m}$, respectively. By 7 days following hASCs seeding on the PCL-P(HEMA-NIPA Am) hydrogel (Fig. 3g), the cells adhered well and covered the surface of the scaffold. Attachment of hASCs to the surface of the PCL-P(HEMA-NIPAAm) hydrogel was associated with a marked morphological adaptation. In the conventional 2D culture system, hASCs acquired spindle-like appearance while 7-days culture on the PCL-P(HEMA-NIPAAm) hydrogel contributed to cell flattening. According to Fig. 3g, hASCs were shaped based on the surface properties of the scaffold. These images give visual evidence that hASCs could attach and undergo dramatic morphological changes. Also, effective cell connection to the scaffold surface indicates that the PCL-P(HEMA-NIPAAm) hydrogel is non-toxic for hASCs. The proximity of the cultured hASCs on the PCL-P(HEMA-NIPAAm) surface shows that the scaffold 
is suitable to maintain the cell-to-cell connection which is vital for the dynamic growth.

\section{Adsorption of serum protein on the PCL-P(HEMA-NIPA Am) S-2 hydrogel}

Protein adsorption onto the surface of materials is extremely related to the biocompatibility of the materials and used to evaluate the biological properties of the scaffolds [52]. For this purpose, the PCL-P(HEMA-NIPA Am) S-2 hydrogel was incubated in culture media containing serum protein for 14days and the level of adsorbed protein assessed by BCA protein quantitative assay. The amount of total serum protein adsorption was significantly high on the hydrogel scaffold compared with serum-free culture medium $(p<0.001)$, showing that significant amounts of serum protein were adsorbed by the PCL-P(HEMA-NIPAAm) hydrogel. Despite these advantages, we found that the levels of released protein were higher compared with the trapped protein content $(p<0.001)$, showing the ability of the synthesized scaffold to release protein to the surrounding niche (Fig. 4a). These findings suggest that the PCL-P(HEMA-NIPAAm) hydrogel may have certain characteristics improving specific protein-affinity and binding strength. Further experiments are needed to determine the effective capacity of protein absorption and release time in a certain period.

\section{Morphological and phenotypical characterization of hASCs}

hASCs were first morphologically characterized using inverted phase-contrast microscopy. As shown in Fig. $4 \mathrm{~b}$, the cells were round up when first inoculated into culture flasks, while the majority of cells were suspended in the cell culture medium. The cells adhered to the Tflask surface and exhibited fibroblast-like, spindleshaped morphology, forming a monolayer with abundant cytoplasm and large nuclei and were in alignment [53]. For each cell, the nucleus was well stacked in the center. The cells rapidly proliferated and reached $70-80 \%$ confluence after 14days. After 3 passages, the surface phenotype of isolated and cultured hASCs was analyzed by flow cytometry-based on the expression of surface markers. According to data from the flow cytometry panel (Fig.4c), isolated cells were highly positive for CD133 and CD44 (ASC surface marker) [54], while the percent of cells expressing CD34 and CD45 (both hematopoietic stem cell surface markers) was below $5 \%$, in agreement with findings from other groups $[55,56]$ and confirming that hASCs possess multipotentiality and stemness features.

hASC viability and proliferation in the PCL-P(HEMA-NIPA Am) S-2 hydrogel

An MTT assay was performed to investigate the viability of hASCs seeded on the PCL-P(HEMA-NIPAAm) hydrogel. The results show a lack of cell toxicity in hASCs plated on the PCL-P(HEMA-NIPAAm) S-2 hydrogel for 14 days, with higher viability in the presence of the hydrogel compared with the control group seeded on standard plastic culture surfaces $(p<0.01$; Fig. $4 d)$, suggesting that the $3 \mathrm{D}$ and porous structure of the scaffold had superior effects on cell survival or due to the presence of PCL in the scaffold since PCL has been reported to enhance the proliferation, adhesion, and growth of hASCs [57]. This suggests that the scaffold and its degradation products have good biocompatibility and can be considered as suitable scaffolds for cartilage tissue engineering applications.

\section{Chondrogenic gene expression profiles of hASCs in the PCL-P (HEMA-NIPAAm) S-2 hydrogel}

Real-time RT-PCR analysis was performed to determine the ability of the PCL-P(HEMA-NIPAAm) S-2 hydrogel to support the chondrogenic differentiation of the hASCs by monitoring the expression of chondrogenic marker genes [58] such as aggrecan (major structural proteoglycan of the cartilage ECM) [59], type-II collagen (main structural component of the cartilage ECM) [60], and SOX9 (essential transcription factor for cartilage formation) [61] and of integrin $\beta 1$ (most common and important receptor for collagen) [62] after 14 days. The results reveal that the expression of the four genes was changed 14 days after being cultured on the scaffold and plastic surfaces in the presence and absence of PDGFBB (Fig. 4e). Specifically, aggrecan expression was upregulated by PDGF-BB in cells cultured on scaffold surface or plastic substrate compared with the non-treated control group (62.44-fold difference, $p<0.0001)$, in agreement with the effects of this growth factor on MSC differentiation [63-65]. However, there was no significant difference in its expression between the groups [hASCs + PDGF-BB] and [hASCs + scaffold + PDGF$\mathrm{BB}](p>0.05)$. Next, type-II collagen expression was significantly higher in all groups compared with the control group (up to 18.09-fold difference), although without reaching statistical significance $(p>0.05)$. Besides, maximal SOX9 expression was achieved in the group [hASCs + scaffold + PDGF-BB] (up to 48.27-fold difference, $p<0.0001$ ), again concordant with the effects of PDGF on MSC chondrogenesis [63-65], while there was no significant difference between the group [hASCs + scaffold] and the control group $(p>0.05)$, suggesting that the presence of the growth factor will be most likely needed as an additional cue in the scaffold approach for optimal chondrogenesis. Finally, integrin $\beta 1$ expression was induced in the groups [hASCs + PDGF-BB] and [hASCs + scaffold + PDGF-BB] compared with the control group (up to 19.55-fold difference, $p<0.001$ ). Compared with the group [hASCs + scaffold], addition of 


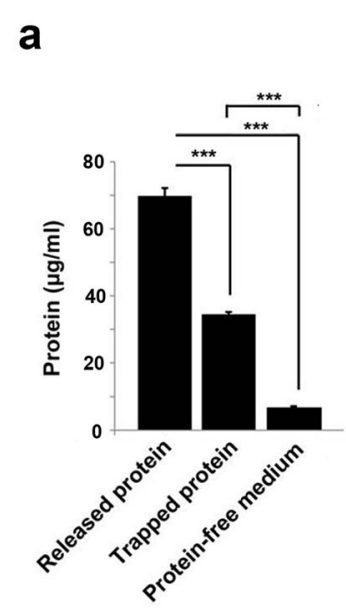

\section{b}

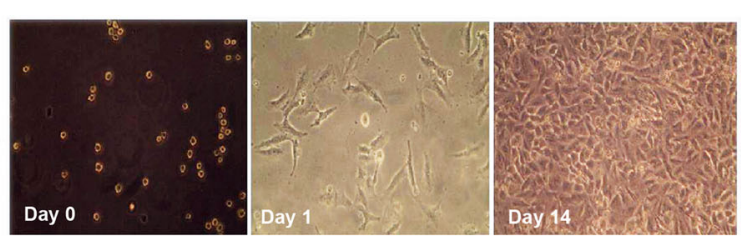

C

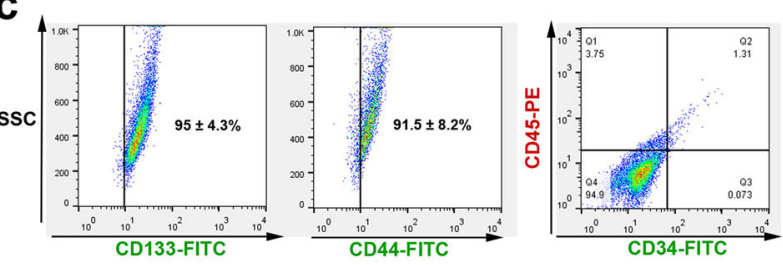

e

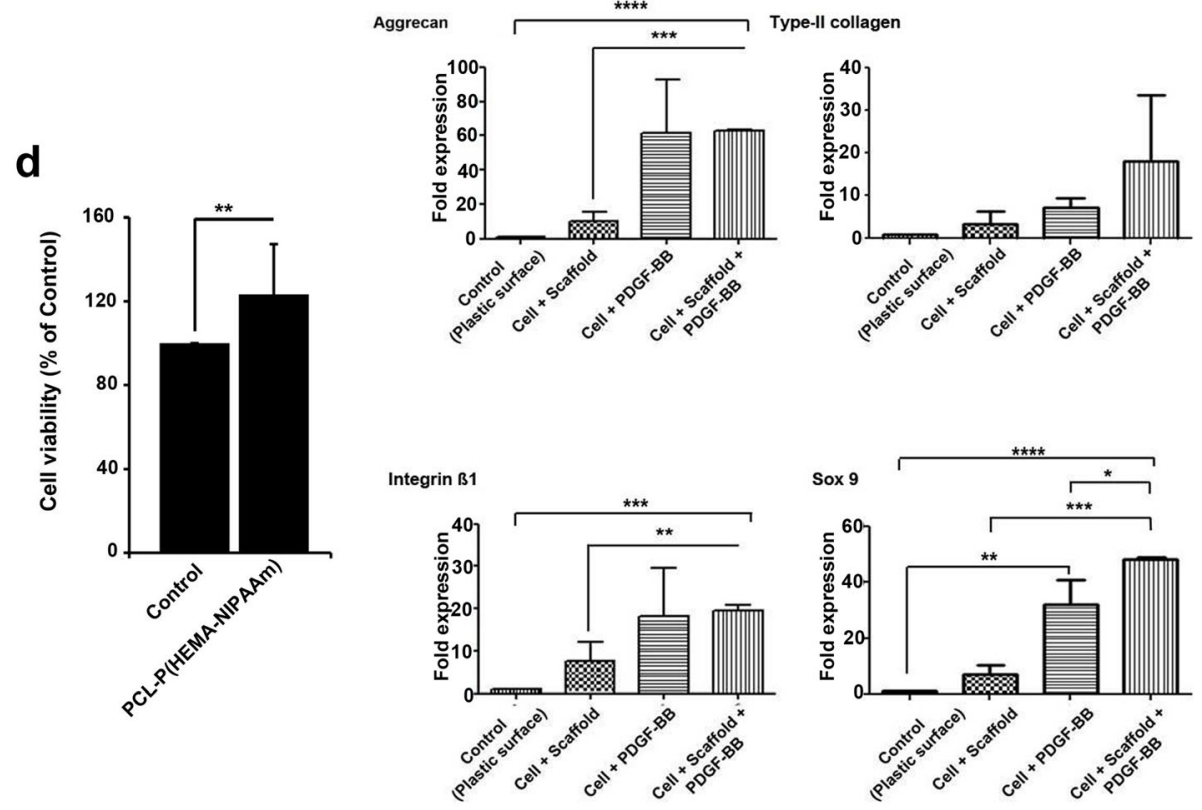

Fig. 4 Measurements of the total protein contents in the PCL-P(HEMA-NIPAAm) S-2 hydrogel after 2 weeks of incubation with serum-containing medium using a BCA assay as described in the Materials and Methods. ${ }^{* *} p<0.001$ (a). Morphological analysis by inverted phase-contrast microscopy (magnification $\times 100$ ) at a different stages of culture and proliferation (days 0, 1, and 14) (b). Characterization of hASCs (c). Detection of hASC surface marker expression (CD133, CD44, CD34, and CD45) by flow cytometry as described in the Materials and Methods. Viability of hASCs in the PCL-P(HEMA-NIPAAm) S-2 hydrogel. Samples were processed using the cytotoxicity assay after 14 days. ${ }^{* *} p<0.01(\mathbf{d})$. Real-time RTPCR analysis of the gene expression profiles in hASCs seeded on the PCL-P(HEMA-NIPAAm) S-2 hydrogel (e). Aggrecan, type-II collagen, SOX9, and integrin $\beta 1$ expression was analyzed using the $2^{-\Delta \Lambda C T}$ method. GAPDH was used as a housekeeping gene and internal control. ${ }^{*} p<0.050$, ${ }^{* *} p<0.010,{ }^{* * *} p<0.001$, and ${ }^{* * *} p<0.0001$

PDGF-BB yielded statically significant differences $(p<$ $0.01)$. Therefore, it could be implied that addition of certain factors increased the chondrogenic capacity of the PCL-P(HEMA-NIPAAm) hydrogel by induction of integrin $\beta 1$. Although the levels of integrin $\beta 1$ increased in the group [hASCs + scaffold], the changes were not statistically significant $(p>0.05)$.

\section{Conclusions}

In this study, new thermosensitive injectable hydrogels based on polyacrylic-polyester hybrids were designed as biodegradable and biocompatible matrices for cartilage tissue engineering. The physicochemical properties of the scaffolds such as swelling ratio, hydrolytic degradation, LCST, mechanical properties, morphologies, pore size, and cytotoxicity were evaluated. The hydrogel underwent a sol-gel transition at physiological conditions ( $\mathrm{pH} 7.4$ and $37^{\circ} \mathrm{C}$ ) with typical rheological properties. According to FESEM micrographs, the PCLP(HEMA-NIPAAm) hydrogel had a porous and nanoparticulate structure with particle size dimensions of about $62-85 \mathrm{~nm}$. The biocompatibility and cell adhesion 
of the fabricated scaffold was evaluated by MTT assay and FESEM. These studies showed good viability and proliferation of hASCs on the scaffold. Additionally, cytocompatibility studies demonstrated that the PNIP AAm-polyester scaffold was not cytotoxic. PDGF-BB was used to induce differentiation of hASCs cultured in plastic surfaces or on the scaffold. The real-time RTPCR results showed that hASCs cultured in the scaffold in the presence of PDGF-BB differentiated towards a chondrocyte phenotype as evidenced by chondrocytespecific gene expression of ECM proteins such as aggrecan and type-II collagen and the cartilage-specific SOX9 transcription factor, as well as the collagen receptor integrin $\beta 1$ after 14 days of culture. These results indicate that the biodegradable and biocompatible hydrogel scaffold embedded with hASCs and PDGF-BB can provide a suitable 3D environment for cell adhesion, proliferation, and differentiation of hASCs for applications in cartilage tissue engineering. This study suggests that the PCLP(HEMA-NIPAAm) hydrogel may serve as a potential structural basis for the in vitro tissue-engineered articular cartilage construct. However, further investigations are necessary to confirm the data in different replicates in vitro. To be even more specific, the development of experimental animal models will help us to monitor the physicochemical behavior and therapeutic benefits of the PCL-P(HEMA-NIPAAm) hydrogel in in vivo conditions by injecting PCL-P(HEMA-NIPAAm) in sites of articular cartilage lesions.

\section{Abbreviations}

2D: Two-dimensional; 3D: Three-dimensional; BCA: Bicinchoninic Acid; BPO: Benzoyl peroxide; BSA: Bovine serum albumin; CP: cloud point; DMEM/ LG: Low-glucose content Dulbecco's modified Eagle medium; DMSO: Dimethyl sulfoxide; E: Elasticity; ECM: Extracellular matrix; FBS: Fetal bovine serum; GAPDH: Glyceraldehyde-3-phosphate dehydrogenase; hASCs: Human adipose-derived stem cells; HEMA: 2-Hydroxyethyl methacrylate; LCST: Lower critical solution temperature; MSCs: Mesenchymal stem cells; MTT: 3-(4,5-dimethylthiazol-2-yl-2,5-diphenyltetrazolium bromide; NIPAAm: N-isopropyl acrylamide; PBS: Phosphate buffered saline; PCL: Poly ( $\varepsilon$-caprolactone); PDGF-BB: Platelet-derived growth factor; PHEMA: Poly (2hydroxyethyl methacrylate); PNIPAAm: Poly N-isopropylacrylamide;

$\mathrm{Sn}(\mathrm{Oct})_{2}$ : Stannous octoate; WS: Working solution; $\varepsilon-\mathrm{CL}$ : Epsilon-caprolactone

\section{Acknowledgments}

The authors wish to thank the personnel of the Stem Cell Research Center and Applied Drug Research Center for guidance and help.

\section{Authors' contributions}

F.V., F.V., R.R., A.M.N., and M.R.R. performed different analyses. S. D. supervised the study. The authors read and approved the final manuscript.

\section{Funding}

This study was supported by a grants from Tabriz University of Medical Sciences (IR.TBZMED.REC.1395.74) and Deputy of Research and Technology, Ministry of Health and Medical Education (grant no. 700/94).

\section{Availability of data and materials}

The datasets used and/or analyzed during the current study are available from the corresponding author on reasonable request.
Ethics approval and consent to participate

Not applicable.

\section{Consent for publication}

Not applicable.

\section{Competing interests}

The authors declare that there is no conflict of interest

\section{Author details}

${ }^{1}$ Stem Cell Research Center, Tabriz University of Medical Sciences, Tabriz, Iran. 2Department of Medicinal Chemistry, Faculty of Pharmacy, Tabriz University of Medical Sciences, Tabriz, Iran. ${ }^{3}$ Department of Molecular Biology, Faculty of Science, Hacettepe University, Ankara, Turkey. ${ }^{4}$ Department of Applied Cell Sciences, Faculty of Advanced Medical Sciences, Tabriz University of Medical Sciences, Tabriz, Iran. ${ }^{5}$ Department of Orthopedy, Tabriz University of Medical Sciences, Tabriz, Iran. ${ }^{6}$ Applied Drug Research Center, Tabriz University of Medical Sciences, Tabriz, Iran.

Received: 25 November 2020 Accepted: 31 January 2021

Published online: 15 February 2021

\section{References}

1. Oliveira JT, Crawford A, Mundy J, Moreira A, Gomes ME, Hatton PV, et al. A cartilage tissue engineering approach combining starch-polycaprolactone fibre mesh scaffolds with bovine articular chondrocytes. J Mater Sci Mater Med. 2007;18(2):295-302.

2. Boopalan P, Sathishkumar S, Kumar S, Chittaranjan S. Rabbit articular cartilage defects treated by allogenic chondrocyte transplantation. Int Orthop. 2006;30(5):357-61.

3. Tissue Engineering Strategies to Increase Osteochondral Regeneration of Stem Cells; a Close Look at Different Modalities. Stem Cell Rev Rep. 2021. https://doi.org/10.1007/s12015-021-10130-0.

4. Zheng L, Fan H, Sun J, Chen X, Wang G, Zhang L, et al. Chondrogenic differentiation of mesenchymal stem cells induced by collagen-based hydrogel: an in vivo study. J Biomed Mater Res Part A. 2010;93(2):783-92.

5. McAdams TR, Mithoefer K, Scopp JM, Mandelbaum BR. Articular cartilage injury in athletes. Cartilage. 2010;1(3):165-79.

6. Alford JW, Cole BJ. Cartilage restoration, part 1: basic science, historical perspective, patient evaluation, and treatment options. Am J Sports Med. 2005;33(2):295-306.

7. Mollon B, Kandel R, Chahal J, Theodoropoulos J. The clinical status of cartilage tissue regeneration in humans. Osteoarthr Cartil. 2013;21(12):182433.

8. Sonia Fathi Karkan, Soodabeh Davaran, Reza Rahbarghazi, Roya Salehi, Abolfazl Akbarzadeh. Electrospun nanofibers for the fabrication of engineered vascular grafts. J Biol Eng. 2019;13(1).

9. Van der Kraan P, Buma P, Van Kuppevelt T, Van Den Berg W. Interaction of chondrocytes, extracellular matrix and growth factors: relevance for articular cartilage tissue engineering. Osteoarthr Cartil. 2002:10(8):631-7.

10. Chen WH, Lai WF, Deng WP, Yang WK, Lo WC, Wu CC, et al. Tissue engineered cartilage using human articular chondrocytes immortalized by HPV-16 E6 and E7 genes. J Biomed Mater Res Part A. 2006;76(3):512-20.

11. Verbruggen G, Wittoek R, Groeneboer S, Vander Cruyssen B, Goemaere S, Elewaut D. Osteochondral repair in synovial joints. Curr Opin Rheumatol. 2007;19(3):265-71

12. Csaki C, Schneider P, Shakibaei M. Mesenchymal stem cells as a potential pool for cartilage tissue engineering. Ann Anatomy-Anatomischer Anzeiger. 2008:190(5):395-412

13. Liu SQ, Tay R, Khan M, Ee PLR, Hedrick JL, Yang YY. Synthetic hydrogels for controlled stem cell differentiation. Soft Matter. 2010;6(1):67-81.

14. Schneider S, Unger M, van Griensven M, Balmayor ER. Adipose-derived mesenchymal stem cells from liposuction and resected fat are feasible sources for regenerative medicine. Eur J Med Res. 2017;22(1):1-11.

15. Kolaparthy LK, Sanivarapu S, Moogla S, Kutcham RS. Adipose tissueadequate, accessible regenerative material. Int J Stem Cells. 2015;8(2):121.

16. Edmondson R, Broglie JJ, Adcock AF, Yang L. Three-dimensional cell culture systems and their applications in drug discovery and cell-based biosensors. Assay Drug Dev Technol. 2014;12(4):207-18.

17. Amani H, Mostafavi $\mathrm{E}$, Arzaghi H, Davaran S, Akbarzadeh A, Akhavan O, et al. Three-dimensional graphene foams: synthesis, properties, biocompatibility, 
biodegradability, and applications in tissue engineering. ACS Biomater Sci Eng. 2018;5(1):193-214.

18. Hokmabad VR, Davaran S, Aghazadeh M, Alizadeh E, Salehi R, Ramazani A. A comparison of the effects of silica and hydroxyapatite nanoparticles on poly ( $\varepsilon$-caprolactone)-poly (ethylene glycol)-poly ( $\varepsilon$-caprolactone)/chitosan Nanofibrous scaffolds for bone tissue engineering. Tissue Eng Regenerative Med. 2018;15(6):735-50.

19. Ponticiello MS, Schinagl RM, Kadiyala S, Barry FP. Gelatin-based resorbable sponge as a carrier matrix for human mesenchymal stem cells in cartilage regeneration therapy. J Biomed Mater Res. 2000;52(2):246-55.

20. Nöth U, Tuli R, Osyczka AM, Danielson KG, Tuan RS. In vitro engineered cartilage constructs produced by press-coating biodegradable polymer with human mesenchymal stem cells. Tissue Eng. 2002;8(1):131-44.

21. Ahmed TA, Dare EV, Hincke M. Fibrin: a versatile scaffold for tissue engineering applications. Tissue Eng B Rev. 2008;14(2):199-215.

22. Buxton AN, Zhu J, Marchant R, West $J \mathrm{~L}$, Yoo JU, Johnstone B. Design and characterization of poly (ethylene glycol) photopolymerizable semiinterpenetrating networks for chondrogenesis of human mesenchymal stem cells. Tissue Eng. 2007;13(10):2549-60.

23. Aung T, Miyoshi H, Tun T, Ohshima N. Chondroinduction of mouse mesenchymal stem cells in three-dimensional highly porous matrix scaffolds. J Biomed Mater Res. 2002;61 (1):75-82.

24. Gao X, Cao Y, Song X, Zhang Z, Xiao C, He C, et al. pH-and thermoresponsive poly ( $\mathrm{N}$-isopropylacrylamide-co-acrylic acid derivative) copolymers and hydrogels with LCST dependent on $\mathrm{pH}$ and alkyl side groups. J Mater Chem B. 2013;1(41):5578-87.

25. Feil H, Bae YH, Feijen J, Kim SW. Effect of comonomer hydrophilicity and ionization on the lower critical solution temperature of $\mathrm{N}$ isopropylacrylamide copolymers. Macromolecules. 1993;26(10):2496-500.

26. Marei NH, El-Sherbiny IM, Lotfy A, El-Badawy A, El-Badri N. Mesenchymal stem cells growth and proliferation enhancement using PLA vs PCL based nanofibrous scaffolds. Int J Biol Macromol. 2016;93:9-19.

27. Kumari A, Yadav SK, Yadav SC. Biodegradable polymeric nanoparticles based drug delivery systems. Colloids Surf B: Biointerfaces. 2010;75(1):1-18.

28. Shih T, Yang J, Jia H, Chen J. Synthesis and properties of biodegradable

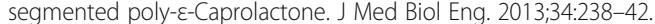

29. Osathanon T, Chuenjitkuntaworn B, Nowwarote N, Supaphol P, Sastravaha $P$, Subbalekha $K$, et al. The responses of human adipose-derived mesenchymal stem cells on polycaprolactone-based scaffolds: an in vitro study. Tissue Eng Regenerative Med. 2014;11(3):239-46.

30. Guo Q, Slavov S, Halley PJ. Phase behavior, crystallization, and morphology in thermosetting blends of a biodegradable poly (ethylene glycol)-type epoxy resin and poly ( $\epsilon$-caprolactone). J Polym Sci B Polym Phys. 2004; 42(15):2833-43.

31. Xu X, Huang J. Synthesis and characterization of well-defined poly (2hydroxyethyl methacrylate-co-styrene)-graft-poly ( $\varepsilon$-caprolactone) by sequential controlled polymerization. J Polym Sci A Polym Chem. 2004; 42(21):5523-9.

32. Ferrari R, Yu Y, Morbidelli M, Hutchinson RA, Moscatelli D. $\varepsilon$-Caprolactonebased macromonomers suitable for biodegradable nanoparticles synthesis through free radical polymerization. Macromolecules. 2011;44(23):9205-12.

33. Valipour F, Esmhosseini M, Nejati K, Kianfar H, Pasdaran A, Davaran S. Synthesis and antibacterial activity of silver nanoparticles embedded in smart poly ( $\mathrm{N}$ isopropylacrylamide)-based hydrogel networks. J Nanotechnol Eng Med. 2011;2(4).

34. Samiei M, Davaran S, Valipour F, Davari A, Ghiasian T, Lotfipour F. Antibacterial efficacy of silver-crosslinked hydrogel Nanocomposite versus sodium hypochlorite and chlorhexidine on enterococcus faecalis for use in root canal infection. Int J Biol Pharm Allied Sci. 2014;3(11):2316-32.

35. Jayakumar R, Ramachandran R, Divyarani V, Chennazhi K, Tamura H, Nair S. Fabrication of chitin-chitosan/nano TiO2-composite scaffolds for tissue engineering applications. Int J Biol Macromol. 2011;48(2):336-44.

36. Cao MJ, Li LY, Xu WL. Synthesis and properties of biodegradable thermoand $\mathrm{pH}$-sensitive poly [(N-isopropylacrylamide)-co-(methacrylic acid)] hydrogels. Polym Degrad Stab. 2010;95(5):719-24.

37. Hu X, Feng L, Xie A, Wei W, Wang S, Zhang J, et al. Synthesis and characterization of a novel hydrogel: salecan/polyacrylamide semi-IPN hydrogel with a desirable pore structure. J Mater Chem B. 2014;2(23):3646-58.

38. Rahmani Del Bakhshayesh A, Mostafavi E, Alizadeh E, Asadi N, Akbarzadeh A, Davaran S. Fabrication of three-dimensional scaffolds based on nanobiomimetic collagen hybrid constructs for skin tissue engineering. ACS Omega. 2018;3(8):8605-11.
39. Bai X, Lü S, Cao Z, Gao C, Duan H, Xu X, et al. Self-reinforcing injectable hydrogel with both high water content and mechanical strength for bone repair. Chem Eng J. 2016;288:546-56.

40. Kemal E, Deb S. Design and synthesis of three-dimensional hydrogel scaffolds for intervertebral disc repair. J Mater Chem. 2012;22(21):10725-35.

41. Min-Liang R, Wei-Feng D, Zheng-Zhen D, Mei-Dong L. Synthesis and selfassembly behavior of random graft terpolymers. Acta Chim Sin. 2008;66(16): 1884-8.

42. Cretu A, Gattin R, Brachais L, Barbier-Baudry D. Synthesis and degradation of poly (2-hydroxyethyl methacrylate)-graft-poly ( $\varepsilon$-caprolactone) copolymers. Polym Degrad Stab. 2004;83(3):399-404.

43. Menzies $K L$, Jones $L$. The impact of contact angle on the biocompatibility of biomaterials. Optom Vis Sci. 2010;87(6):387-99. https://doi.org/10.1097/OPX. Ob013e3181da863e.

44. Jayakumar R, Ramachandran R, Kumar PS, Divyarani V, Srinivasan S, Chennazhi K, et al. Fabrication of chitin-chitosan/nano ZrO2 composite scaffolds for tissue engineering applications. Int J Biol Macromol. 2011;49(3): 274-80

45. Unnithan AR, Park CH, Kim CS. Nanoengineered bioactive 3D composite scaffold: a unique combination of graphene oxide and nanotopography for tissue engineering applications. Compos Part B. 2016;90:503-11.

46. Peter M, Ganesh N, Selvamurugan N, Nair S, Furuike T, Tamura H, et al. Preparation and characterization of chitosan-gelatin/nanohydroxyapatite composite scaffolds for tissue engineering applications. Carbohydr Polym. 2010;80(3):687-94

47. Chao GT, Qian ZY, Huang MJ, Kan B, Gu YC, Gong CY, et al. Synthesis, characterization, and hydrolytic degradation behavior of a novel biodegradable $\mathrm{pH}$-sensitive hydrogel based on polycaprolactone, methacrylic acid, and poly (ethylene glycol). J Biomed Mater Res A. 2008; 85(1):36-46

48. Hu C-H, Zhang X-Z, Zhang L, Xu X-D, Zhuo R-X. Temperature-and pHsensitive hydrogels to immobilize heparin-modified PEI/DNA complexes for sustained gene delivery. J Mater Chem. 2009;19(47):8982-9.

49. Pompe W, Worch H, Epple M, Friess W, Gelinsky M, Greil P, et al. Functionally graded materials for biomedical applications. Mater Sci Eng A. 2003:362(1-2):40-60.

50. Chan B, Leong K. Scaffolding in tissue engineering: general approaches and tissue-specific considerations. Eur Spine J. 2008;17(4):467-79.

51. Diaz Lantada A, Alarcon Iniesta H, Pareja Sanchez B, García-Ruíz JP. Freeform rapid prototyped porous PDMS scaffolds incorporating growth factors promote chondrogenesis. Adv Mater Sci Eng. 2014;2014:1.

52. Fu C, Bai H, Zhu J, Niu Z, Wang Y, Li J, et al. Enhanced cell proliferation and osteogenic differentiation in electrospun PLGA/hydroxyapatite nanofibre scaffolds incorporated with graphene oxide. PLoS One. 2017;12(11): e0188352.

53. Nguyen HT, Van Pham P. Conversion of human adipose derived stem cells into endothelial progenitor cells. Progress in Stem Cell. 2017:4(3-4):229-40.

54. Wang JM, Gu Y, Pan CJ, Yin LR. Isolation, culture and identification of human adipose-derived stem cells. Exp Ther Med. 2017:13(3):1039-43.

55. Lee RH, Kim B, Choi I, Kim H, Choi HS, Suh K, et al. Characterization and expression analysis of mesenchymal stem cells from human bone marrow and adipose tissue. Cell Physiol Biochem. 2004;14(4-6):311-24.

56. Dicker A, Le Blanc K, Åström G, van Harmelen V, Götherström C, Blomqvist $L$, et al. Functional studies of mesenchymal stem cells derived from adult human adipose tissue. Exp Cell Res. 2005;308(2):283-90.

57. Xue R, Qian Y, Li L, Yao G, Yang L, Sun Y. Polycaprolactone nanofiber scaffold enhances the osteogenic differentiation potency of various human tissue-derived mesenchymal stem cells. Stem Cell Res Ther. 2017;8(1):148.

58. Munirah S, Ruszymah B, Samsudin O, Badrul A, Azmi B, Aminuddin B. Autologous versus pooled human serum for articular chondrocyte growth. $J$ Orthop Surg. 2008;16(2):220-9.

59. Kiani C, Liwen C, Wu YJ, Albert JY, Burton BY. Structure and function of aggrecan. Cell Res. 2002;12(1):19-32.

60. Armiento AR, Alini M, Stoddart MJ. Articular fibrocartilage-why does hyaline cartilage fail to repair? Adv Drug Deliv Rev. 2019;146:289-305.

61. Leung VY, Gao B, Leung KK, Melhado IG, Wynn SL, Au TY, et al. SOX9 governs differentiation stage-specific gene expression in growth plate chondrocytes via direct concomitant transactivation and repression. PLoS Genet. 2011;7(11):e1002356.

62. Shakibaei M, Merker H-J. B1-integrins in the cartilage matrix. Cell Tissue Res. 1999;296(3):565-73. 
63. Tokunaga A, Oya T, Ishii Y, Motomura H, Nakamura C, Ishizawa S, et al. PDGF receptor $\beta$ is a potent regulator of mesenchymal stromal cell function. J Bone Miner Res. 2008;23(9):1519-28.

64. Xu L, Wu Y, Xiong Z, Zhou Y, Ye Z, Tan W-S. Mesenchymal stem cells reshape and provoke proliferation of articular chondrocytes by paracrine secretion. Sci Rep. 2016;6(1):1-13.

65. Barbon S, Stocco E, Macchi V, Contran M, Grandi F, Borean A, et al. Plateletrich fibrin scaffolds for cartilage and tendon regenerative medicine: from bench to bedside. Int J Mol Sci. 2019;20(7):1701.

\section{Publisher's Note}

Springer Nature remains neutral with regard to jurisdictional claims in published maps and institutional affiliations.

Ready to submit your research? Choose BMC and benefit from:

- fast, convenient online submission

- thorough peer review by experienced researchers in your field

- rapid publication on acceptance

- support for research data, including large and complex data types

- gold Open Access which fosters wider collaboration and increased citations

- maximum visibility for your research: over $100 \mathrm{M}$ website views per year

At $\mathrm{BMC}$, research is always in progress.

Learn more biomedcentral.com/submissions 